\title{
Yem Üretimi Amacıyla Yetiştirilen Sakız Fasulyesinde (Cyamopsis tetragonoloba (L.) Taub.) Farklı Sıra Aralıklarının Ot Verimi ve Kalitesi Üzerine Etkileri
}

\author{
Gürkan CEBECI $\dot{1}^{1} \quad$ Firat ALATÜRK ${ }^{2} \quad$ Ahmet GÖKKUŞ ${ }^{2} \quad$ Selçuk BİRER ${ }^{3}$ \\ ${ }^{1}$ Ziraat Yüksek Mühendisi, BURSA \\ ${ }^{2}$ ÇOMÜ Ziraat Fakültesi Tarla Bitkileri Bölümü, ÇANAKKALE \\ ${ }^{3}$ ÇOMÜ Bayramiç MYO, ÇANAKKALE \\ $\triangle$ : agokkus@yahoo.com
}

Geliş (Received): 03.11.2017

Kabul (Accepted): 15.12.2017

\begin{abstract}
ÖZET: Bu çalışmada, sakız fasulyesinin (Cyamopsis tetragonobla (L.) Taub.) farklı sıra arası ile ekiminin ot verimi ve kalitesi üzerine etkileri belirlenmiştir. Deneme Çanakkale Onsekiz Mart Üniversitesi Dardanos Yerleşkesi Ziraat Fakültesi uygulama alanında 2015 ve 2016 yıllarında tarla denemesi olarak yürütülmüştür. Araştırma tesadüf blokları deneme desenine göre 3 tekerrürlü olarak kurulmuş ve sıra aralıkları 20, 40, 60, 80 ve $100 \mathrm{~cm}$ olacak şekilde tertiplenmiştir. Araştırmadan elde edilen sonuçlara göre, sıra aralıklarının yeşil ve kuru ot verimi ile otun ham protein, NDF ve ADF oranları üzerine etkisi önemli olurken, ham kül içeriğine etkisi önemsiz bulunmuştur. İncelenen bütün özelliklerde en yüksek sonuçlara $20 \mathrm{~cm}$ sıra aralıklarında ulaşılırken, en düşük değerler $100 \mathrm{~cm}$ sıra aralığında tespit edilmiştir. Sonuç olarak, sakız fasulyesinin ot üretimi amacıyla yetiştirilmesi halinde $20 \mathrm{~cm}$ sıra aralı̆̆ ile ekilmesi uygun bulunmuştur.

Anahtar Kelimeler: Sakız fasulyesi, sıra arası, ot verimi, ham protein, NDF.
\end{abstract}

\section{Effects of Different Row Spacings on the Yield and Quality of Cyamopsis tetragonoloba (L.) Taub. Grown for Feed Production Purpose}

\begin{abstract}
In this study, the effects of different row spacing and sowing have been determined on the yield and quality characteristics of the Guar (Cyamopsis tetragonoloba (L.) Taub.). The experiment was conducted in Çanakkale Onsekiz Mart University at Dardanelles Research and Experimental Unit of the Faculty of Agriculture in 2015 and 2016 (two years) as field experiment. The research has been established by using randomized complete block design with 3 replications, and the row to row distances were arranged as 20, 40,60, 80 and $100 \mathrm{~cm}$. According to the obtained results, the effect of row spacings on fresh and dry hay yield and crude protein, NDF and ADF ratios was found significantly important, while had none significant effect on crude ash content. The highest results were obtained in $20 \mathrm{~cm}$ row spacings, while the lowest values were found in $100 \mathrm{~cm}$ row spacings in all examined characteristic features. As a result, $20 \mathrm{~cm}$ row spacing is suitable for sowing the Guar for hay production purpose.

Keywords: Guar, row spacing, hay yield, crude protein, NDF
\end{abstract}

\section{GíRiş}

Ülkemizde kaliteli kaba yem açığının kapatılması amacıyla çayır ve mera alanlarının yönetim ilkelerine uygun şekilde kullanılması yanında, yem bitkileri ekim alanların artırılması amaciyla yaygın olarak yetiştiriciliği yapılan bitkilerin üretimi ile beraber yeni yem bitkisi türlerinin yetiştirilme yolları da aranmalıdır (Sağlamtimur ve ark., 1986). Bu bakımdan sakız fasulyesi (guar) yazlık baklagil yem bitkisi olarak düşünülebilecek iyi bir seçenek olabilir. Sakız fasulyesi yüksek besin değerine sahip, kurağa dayanıklı, dik ve derin köklü baklagil olup, Hindistan ve Pakistan kökenli dünyada kurak, kurak-yarı, tropik-subtropik bölgelerde yetiştirilen bir bitkidir. Yetersiz yağış altında büyüyebilmesine rağmen, üretkenliği (verimi) düşüktür (Kuhad ve Sheoran, 1986). Sakız fasulyesi dipteki boğumlarından çıkan çok sayıda güçlü dallara sahip, 0.5-3.0 m boyunda, gür dallanan tek y1llık ve kendine döllenen bir bitkidir. Tohumları \%27.0-32.2 oranında protein ve $\% 50$ besidoku içermekte olup, besidokunun \%42'si zamktır (guar zamkı) (Anderson, 1949; Whistler ve Hymowitz, 1979). Diğer baklagil tohumlarının aksine sakız fasulyesi tohumları soğuk su içinde akışkansı bir jel formunda olan galaktomannan zamk1 içerir. Bu yüzden gıda ve gıda dışı madde olarak giderek önem kazanmaktadır. Yüksek rafine edilmiş guar zamk1 yumuşak dondurma, hızlı puding ve kremşanti katılaştırıcısı olarak kullanılırken, düşük dereceli guar zamkı tekstil, kağıt, petrol, madencilik, ilaç ve kozmetik sanayisinde kullanılmaktadır (Undersander ve ark., 1991). Sakız fasulyesi Asya'da sebze, yem, yeşil gübre ve toprak koruyucu örtü olarak yetiştirilen yazlık bir bitkidir (Arora ve Pahuja, 2008). Bitki hayvan besleme için yazlık yem bitkileri talebi ve kullanılabilirliği arasındaki açı̆̆ı azaltmak için yağmurla beslenen alanlarda başarılı bir şekilde kullanılabilmektedir. Baklagil olduğundan, kendisi ve kendisinden sonraki ürün için atmosfer azotunu bağlamak suretiyle toprağın üretkenliğini arttırmaktadır (Bewal ve ark., 2009). Son yıllarda dünyada sakız fasulyesine olan talep hızla artmaktadır. Gerçi bu talep guar zamkı ve guar bazlı ürünler üzerinde yoğunlaşmış olmakla birlikte, özellikle 
fazla dallanan tiplerinden yem bitki olarak yararlanmak da mümkündür.

Özellikle endüstri bitkilerinin yoğun yetiștirildiği bölgelerde yem bitkileri ekim alanlarının artırılması için, baklagil olması hasebiyle yazlık ana ve ara ürün (2. ürün) olarak ekim nöbetine dahil edilmesinde yarar görülmektedir. Ülkemizin kıyı bölgeleri bunun için oldukça elverişli bir iklime sahiptir (Açıkgöz, 2004). Bu sebeple bu araştırmada ülkemiz için yeni bir yazlık baklagil yem bitkisi olan sakız fasulyesinin Çanakkale koşullarında yetiştirilme imkânları ve yetiştiricilikte en uygun sıra aralığının ne olması gerektiği araştırılmıştır.

\section{MATERYAL ve YÖNTEM}

Araștırma, Canakkale Onsekiz Mart Üniversitesi Dardanos Yerleşkesi Ziraat Fakültesi uygulama alanında 2015 ve 2016 yıllarında yürütülmüştür. Denemenin yürütüldüğü dönemde aylık ortalama sicaklık ilk yıl $17.8^{\circ} \mathrm{C}$, ikinci yll ise $16.0^{\circ} \mathrm{C}$ olmak suretiyle uzun yıllara göre $\left(15.4^{\circ} \mathrm{C}\right)$ göre daha yüksek bulunmuştur. Deneme yıllarında yıllık toplam yağış miktarları (ilk yıl $650.1 \mathrm{~mm}$, ikinci yıl $443.6 \mathrm{~mm}$ ) uzun yillar ortalamasının $(670.2 \mathrm{~mm})$ altında kalmıştır. Denemenin yürütüldüğ̈̈ alanın toprakları killi-tınlı olup, hafif alkali özellik göstermektedir (Özcan ve ark., 2003). Araştırmada bitki materyali olarak sakız fasulyesinin (Cyamopsis tetragonoloba (L.) Taub.) Hindistan'dan temin edilen Pusa Nevbahar/Sadabahar çeşidi kullanılmıştır. Bitkiler Mayıs-Ekim aylarında yetiştirilmiş̧ir. Denemede sakız fasulyesi 5 farklı sıra aralığına $(20,40,60,80$ ve $100 \mathrm{~cm})$ ekilmiştir. Tesadüf blokları deneme desenine göre 3 tekerrürlü olarak kurulan denemede, her parsel $5 \mathrm{~m}$ uzunluğunda 5 sıradan oluşmuştur. Ekim markörle çiziler açılarak her sıraya 34 tohum gelecek şekilde elle yapılmıştır. Sıra üzeri bitki sıklığı sabit olacak şekilde $15 \mathrm{~cm}$ olarak belirlenmiştir. Toprağın nem durumuna göre bitkiler yaklaşık haftada 2 gün $\% 100$ tarla kapasitesinde olacak şekilde sulanmıştır. Ot için hasat çiçeklenme sonu ile alt baklaların olgunlaşmaya başladığı dönemde yapılmıştır. Ham protein ve ham kül analizleri AOAC (1990)'a göre, NDF ve ADF analizleri ise Van Soest ve ark. (1991)'na göre yapılmıştır. Elde edilen verilerin varyans analizinde SAS istatistik paket programı kullanılmıştır (SAS, 1999).

\section{BULGULAR ve TARTIŞMA}

Ot verimi: Yapılan araştırmada farklı sıra aralıklarında yetiştirilen sakız fasulyesinin yeşil ot verimi sadece sira arası uygulamalara, kuru ot verimleri ise sıra arası ve yıllara göre istatistiki olarak önemli olmuştur. Ortalama en yüksek yeşil ot verimi $(2268.4 \mathrm{~kg}$ $\left.\mathrm{da}^{-1}\right) 20 \mathrm{~cm}$, en düşük verim $\left(1384.1 \mathrm{~kg} \mathrm{da}^{-1}\right)$ ise $100 \mathrm{~cm}$ sıra aralıklarına ekilen parsellerde belirlenmiştir. Kuru ot verimi de yeşil ota benzer şekilde sıra aralı̆̆ının artışına bağlı olarak azalmıştır. En yüksek kuru ot verimi $20 \mathrm{~cm}\left(739.7 \mathrm{~kg} \mathrm{da}^{-1}\right)$, en az ise $100 \mathrm{~cm}(322.3$ $\left.\mathrm{kg} \mathrm{da}^{-1}\right)$ sıra aralığına ekilen parsellerde belirlenmiştir. Bunun yanında kuru ot verimi araştırmanın ikinci yılında daha yüksek (618.3 $\mathrm{kg} \mathrm{da}^{-1}$ ) çıkmıştır (Çizelge $1)$.

Çizelge 1. Farklı sıra aralıkları ile ekilen sakız fasulyesinin yeşil ve kuru ot verimleri $\left(\mathrm{kg} \mathrm{da}^{-1}\right)$

\begin{tabular}{|c|c|c|c|c|c|c|}
\hline \multirow{2}{*}{$\begin{array}{c}\text { Sira aralı̆̆ } \\
(\mathbf{c m})\end{array}$} & \multicolumn{3}{|c|}{ Yeşil ot verimi $\left(\mathrm{kg} \mathrm{da}^{-1}\right)$} & \multicolumn{3}{|c|}{ Kuru ot verimi $\left(\mathrm{kg} \mathrm{da}^{-1}\right)$} \\
\hline & 2015 & 2016 & Ortalama & 2015 & 2016 & Ortalama \\
\hline 20 & 2323.7 & 2213.1 & $2268.4 \mathrm{a}$ & 600.4 & 879.0 & $739.7 \mathrm{a}$ \\
\hline 40 & 2041.7 & 1969.1 & $2005.4 \mathrm{ab}$ & 448.5 & 723.7 & $586.1 \mathrm{~b}$ \\
\hline 60 & 1569.7 & 1785.4 & $1677.5 \mathrm{bc}$ & 355.1 & 638.3 & $496.7 \mathrm{bc}$ \\
\hline 80 & 1547.9 & 1706.0 & $1627.0 \mathrm{c}$ & 329.7 & 471.3 & $400.5 \mathrm{~cd}$ \\
\hline 100 & 1197.9 & 1570.3 & $1384.1 \mathrm{c}$ & 265.2 & 379.4 & $322.3 \mathrm{~d}$ \\
\hline Ortalama & 1736.2 & 1848.8 & - & $399.8 \mathrm{~b}$ & $618.3 \mathrm{a}$ & - \\
\hline Önemlilik & $\begin{array}{l}\text { Yeşil ot ver } \\
\text { Kuru ot ver }\end{array}$ & $\begin{array}{l}\text { rass: } 0.0 \\
\text { rasi: } 0.0\end{array}$ & $\begin{array}{l}: 0.2852, \mathrm{P} \\
: 0.0001, \mathrm{P}\end{array}$ & 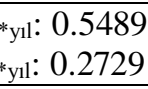 & & \\
\hline
\end{tabular}

Yıllar arasında ortaya çıkan verim farklılı̆̆ı, ikinci yılda ortalama sıcaklığın fazla olmasından dolayı kuru madde oranındaki artıştan ileri gelmiş olabilir. Sıra arası mesafenin artışına bağlı olarak yeşil ve kuru ot verimlerinde önemli oranda azalma gözlenmiştir. Dar sıra aralıklarında yetiştirilen bitkiler arasındaki rekabet daha fazladır. Ancak geniş sıra aralıklarında birim alandaki bitki sayısı ve bitkiler arasındaki rekabet az olmakla birlikte, alandan (su, besin elementleri, ışık vb. gibi faktörlerden) yeterince yararlanılamadığı için, toplam organik kütle üretimi de azalmaktadır. Buna karşılık çok sık ekimlerde bitkiler arasında su ve $1 s ̧ 1 k$ gibi büyüme faktörlerine olan talep artacağından, büyüme ve gelişme azalacaktır (Gökkuş ve ark., 2015). Birim alandaki bitki sayısının artması, bitki başına olan azalmayı belirli bir noktaya kadar dengelemektedir. $\mathrm{Bu}$ nokta bitki türlerine ve yetiştirme şartlarında göre değişmektedir. Sonuçta her tür için uygun bir bitki sıklığı ortaya çıkmaktadır. Bu araştırma sonucu da, ot için yetiştirilen sakız fasulyesi için en uygun sıra aralığının $20 \mathrm{~cm}$ arasında olması gerektiğini göstermiştir. Yapılan çalışmalarda da benzer sonuçlar elde edilmiştir (Graybill ve ark., 1991; Cox ve Otis, 1993; Mohamed ve ark., 2002).

Ham protein oranı: Farklı sira aralıkları ile yetiştirilen sakız fasulyesinin ham protein içeriği sıra arası ve sıra arası*yıllara göre istatistiki olarak önemli olmuştur. En yüksek ham protein içeriği $20 \mathrm{~cm}(\% 12.8)$, en az ise $100 \mathrm{~cm}$ (\%10.9) sira aralıklarında belirlenmiștir. Y1l içerisinde en yüksek ham protein oranı \%13.7 ile $20 \mathrm{~cm}$ sıra aralığının ikinci yılında, en 
az ise yine aynı yilın 100 ve $80 \mathrm{~cm}$ sira aralıklarında (\%10.0 ve \%10.6 ile) tespit edilmiştir (Çizelge 2).

Araştırmada sıra aralığının artışına bağlı olarak otun ham protein içeriğinde azalma olmuştur. Sik ekimlerde bitkiler rekabetten dolayı olgunlaşmaları daha geç olmakta ve buna bağlı olarak da bünyesindeki su ve besin elementleri daha fazla bulunmaktadır. Ayrıca geniş sıraya ekimlerde bitkiler daha fazla dallanarak daha kalın gövde oluşturmaktadır. Bitkilerde gövde kalınlığının artması ile ham protein oranı azalırken hücre çeperi bileşenleri artmaktadır (Nelson ve Moser, 1994). Nitekim korungada yapılan çalışmada sıra aralıklarının artışına bağlı olarak protein içeriğinde azalma kaydedilmiştir (Türk ve Çelik, 2006). Farklı bitkilerle de olsa, yapılan başka çalışmalarda da benzer sonuçlar elde edilmiştir (Cupina ve ark., 1999; Hakyemez, 2000; Türk, 2005).

Çizelge 2. Farklı sıra aralıkları ile ekilen sakız fasulyesinin ortalama ham protein oranları (\%)

\begin{tabular}{|c|c|c|c|}
\hline \multirow{2}{*}{ Sıra aralığı (cm) } & \multicolumn{3}{|c|}{ Ham protein oranı (\%) } \\
\hline & 2015 & 2016 & Ortalama \\
\hline 20 & $12.0 \mathrm{~b}$ & $13.7 \mathrm{a}$ & $12.8 \mathrm{~A}$ \\
\hline 40 & $11.9 \mathrm{~b}$ & $12.1 \mathrm{~b}$ & $12.0 \mathrm{~B}$ \\
\hline 60 & $12.3 \mathrm{~b}$ & $11.5 \mathrm{bc}$ & $11.9 \mathrm{~B}$ \\
\hline 80 & $11.8 \mathrm{~b}$ & $10.6 \mathrm{~cd}$ & $11.2 \mathrm{C}$ \\
\hline 100 & $11.8 \mathrm{~b}$ & $10.0 \mathrm{~d}$ & $10.9 \mathrm{C}$ \\
\hline Ortalama & 12.0 & 11.6 & \\
\hline Önemlilik & \multicolumn{3}{|c|}{$\mathrm{P}_{\text {srra arasi }}: 0.0001, \mathrm{P}_{\text {yll }}: 0.0487, \mathrm{P}_{\text {srra arasi }}{ }^{*}$ yll $: 0.0002$} \\
\hline
\end{tabular}

Ham kül oranı: Farklı sıra aralıklarında yetiştirilen sakız fasulyesinin ham kül içeriği sadece sıra arası*yıl etkileşimine göre önemli olmuştur. Buna göre en yüksek ham kül oranı \%12.6 ile $100 \mathrm{~cm}$ sıra aralığında belirlenirken, en düşük kül \%9.7 ile $20 \mathrm{~cm}$ sıra aralığına ekilen parsellerin otunda tespit edilmiştir (Çizelge 3).

Çizelge 3. Farklı sıra aralıkları ile ekilen sakız fasulyesinin ortalama ham kül oranları (\%)

\begin{tabular}{cccc}
\hline \multirow{2}{*}{ Sıra aralı̆̆ $\mathbf{( c m )}$} & \multicolumn{3}{c}{ Ham kül oranı (\%) } \\
\cline { 2 - 4 } & $\mathbf{2 0 1 5}$ & $\mathbf{2 0 1 6}$ & Ortalama \\
\hline 20 & $12.0 \mathrm{ab}$ & $9.7 \mathrm{~d}$ & 10.9 \\
40 & $11.5 \mathrm{abc}$ & $10.5 \mathrm{~cd}$ & 11.0 \\
60 & $11.7 \mathrm{abc}$ & $11.6 \mathrm{abc}$ & 11.6 \\
80 & $10.9 \mathrm{bcd}$ & $12.2 \mathrm{ab}$ & 11.6 \\
100 & $11.4 \mathrm{abc}$ & $12.6 \mathrm{a}$ & \\
\hline Ortalama & 11.5 & 11.3 & \\
\hline Önemlilik & $\mathrm{P}_{\text {srra arası }}: 0.1211, \mathrm{P}_{\text {yll }}: 0.4819, \mathrm{P}_{\text {srra arası }}{ }^{\text {yll }}: 0.0052$ & \\
\hline
\end{tabular}

NDF ve ADF oranlart: Farklı sira arası ile ekimlerin otun NDF ve ADF oranlarına etkisi yıllara ve sıra aralıklarına göre önemli bulunmuştur. En yüksek NDF oranı (\%48.9) $20 \mathrm{~cm}$, en az NDF oranı (\%37.8) ise $100 \mathrm{~cm}$ sira aralıklarına ekilen parsellerin otunda belirlenmiş̧tir. Bunun yanında benzer şekilde en yüksek ADF oranı (\% 24.1) $20 \mathrm{~cm}$ sira aralığında, en az ise 80 ve $100 \mathrm{~cm}(\% 21.6$ ve 20.6) aralıklarla ekimlerde tespit edilmiştir (Çizelge 4).

Çizelge 4. Farklı sıra aralıklarına göre sakız fasulyesinin ortalama NDF ve ADF oranları (\%)

\begin{tabular}{|c|c|c|c|c|c|c|}
\hline \multirow{2}{*}{$\begin{array}{l}\text { Sıra aralığı } \\
(\mathbf{c m})\end{array}$} & \multicolumn{3}{|c|}{ NDF oranı (\%) } & \multicolumn{3}{|c|}{ ADF oranı (\%) } \\
\hline & 2015 & 2016 & Ortalama & 2015 & 2016 & Ortalama \\
\hline 20 & 45.3 & 42.4 & $48.9 \mathrm{a}$ & 24.8 & 23.4 & $24.1 \mathrm{a}$ \\
\hline 40 & 40.8 & 40.9 & $40.9 \mathrm{~b}$ & 24.2 & 22.2 & $23.2 \mathrm{ab}$ \\
\hline 60 & 38.4 & 39.4 & $38.9 \mathrm{bc}$ & 23.5 & 22.1 & $22.8 \mathrm{~b}$ \\
\hline 80 & 41.8 & 38.7 & $40.3 \mathrm{~b}$ & 22.1 & 21.0 & $21.6 \mathrm{c}$ \\
\hline 100 & 39.8 & 35.9 & $37.8 \mathrm{c}$ & 22.3 & 18.9 & $20.6 \mathrm{c}$ \\
\hline Ortalama & $41.2 \mathrm{a}$ & $39.5 \mathrm{~b}$ & & $23.4 \mathrm{~b}$ & $21.5 \mathrm{a}$ & \\
\hline Önemlilik & $\begin{array}{l}\text { NDF: } P_{\text {srra }} \\
\text { ADF: } P_{\text {srra }}\end{array}$ & $\begin{array}{l}\text { 02. } \mathrm{P}_{\mathrm{yll}} \text { : } \\
\text { 28. } \mathrm{P}_{\mathrm{yll}} \text { : }\end{array}$ & $\begin{array}{l}\text { 1. } \mathrm{P}_{\text {srra arası }}{ }^{*} \mathrm{yl} \\
\text { 5. } \mathrm{P}_{\text {Srra aras } 1{ }^{*} \mathrm{yl}}\end{array}$ & & & \\
\hline
\end{tabular}

Genel olarak sıra arası mesafenin artışına bağlı olarak hücre çeperi bileşenlerinde azalma görülmüsşür. Dar sira aralıkları ile ekimde ince de olsa birim alandaki sap miktarı artmakta, dallanma azalmaktadır. Genişs sıra aralıklarında ise daha kalın ana saplara karşılık daha çok yan dal oluşması, sıra aralıklarının artışı ile çeper bileşenlerinin de artmasının saplamıştır. Zira bitkilerde sap oranı ile hücre çeperi bileşenleri arasında doğrusal bir ilişki bulunmaktadır (Nelson ve Moser, 1994). Yem bezelyesinin farklı sıra aralıklarına göre hücre çeperi bileşenlerinin değişiminin incelendiği bir araştırma sonucunda, çeper bileşenleri önemsiz de olsa sıra 
aralığının artışına bağlı olarak artmıştır (Tan ve ark., 2013). Fakat tersi sonuçların elde edildiği araştırma bulguları da kaydedilmiştir (Albayrak ve ark., 2011; Kuşvuran ve ark., 2014).

\section{SONUC}

Ülkemizde çiftlik hayvanları yetiştiriciliğinde kaba yem temini önemli bir sorundur. Bu sorunun üstesinde gelmek için yem bitkileri ekim alanlarının artırılması ve üretimin yıl içerisine dağıtılması gerekmektedir. Özellikle yazlık ekilecek baklagil yem bitkisi türlerinde bir yetersizlik söz konusudur. Bu açıdan sakız fasulyesi iyi bir seçenek olabilecek durumdadır. Bu nedenle bu çalışmada, yörede ve ülkemizde yem bitkisi olarak sakız fasulyesi yetiştiriciliğinde önemli bir husus olan sıra aralığı ilk kez denenmiştir. Araştırmada, sakız fasulyesinin dallanma gösteren tiplerinin yazlık baklagil yem bitkisi olarak yetiştirilebileceği ve bu yetiştiricilikte en yüksek ot üretimi için bitkilerin $20 \mathrm{~cm}$ aralıkla ekilmesi sonucuna ulaşıllmıştır.

\section{KAYNAKLAR}

Açıkgöz E, Uzun A, Bilgili U, Sincık M 2004. Yield and quality performances of forage type pea strains contrasting leaf types. European J. Agronomy, 22: 85-94.

Albayrak S, Turk M, Yuksel O 2011. Effect of row spacing and seeding rate on Hungarian vetch yield and quality. Turk J Field Crops, 16(1): 54-58.

Anderson E 1949. Endosperm mucilages of legumes. Ind. Eng. Chem., 41: 2887-2890.

AOAC 1990. Official Methods of Analysis (15th Ed.). Association of Official Analytical Chemists, Arlington, VA.

Arora RN, Pahuja SK 2008. Mutagenesis in guar (Cyamopsis tetragonoloba (L.) Taub.). Plant Mutation Reports, 2(1): 7-9.

Bewal S, Purohit J, Kumar A, Khedasana R, Rama Rao S 2009. Cytogenetical investigations in colchicineinduced tetraploids of Cyamopsis tetragonoloba $\mathrm{L}$. Czech J. Genet. Plant Breed., 45(4): 143-154.

Cox WJ, Otis DJ 1993. Grain and Silage Responses of Commercial Corn Hybrids to Plant Densities. Agronomy Abstract, ASA, Madison, WI, p. 132.

Cupina B, Eric P 1999. The Effects of Sowing method and seeding rate on yield and quality of sainfoin $(O$. sativa L.) forage. Scientia Agriculturae Bohemica 30: 107-114.

Gökkuş A, Kantar F, Karadoğan T, Koç A 2015. Tarla Bitkileri (üçüncü baskı). Atatürk Üni. Ziraat Fak. Ders Yay. No: 188, 211s.

Graybill JS, Cox WJ, Otis DJ 1991. Yield and quality of forage maize as influenced by hybrid, planting date and plant density. Agronomy J., 83: 559-564.

Hakyemez BH 2000. Çok Yillık Yonca, Korunga ve Nohut Geveninde Bitki Sıklığının Yem Verimine Etkileri. Ankara Üni. Fen Bil. Enst. Tarla Bitk. Anabilim Dalı (Doktora Tezi), Ankara, 157s.
Kuhad MS, Sheoran IS 1986. Physiological and biological changes in cluster bean (Cyamopsis tetranogoloba L.) genotype under water stress. Indian J. Plant Physiology, 29(1): 46-52.

Kuşvuran A, Kaplan M, Nazli RI 2014. Effects of mixture ratio and row spacing in Hungarian vetch (Vicia pannonica Crantz.) and annual ryegrass (Lolium multiflorum Lam.) intercropping system on yield and quality under semiarid climate conditions. Turkish Journal of Field Crops, 19(1): 118-128.

Mohamed MF, Keutgen N, Tawfik AA, Noga G 2002. Dehydration avoidance responses of tepary bean lines differing in drought resistance. J. Plant Physiol., 159: 31-38.

Nelson CJ, Moser LE 1994. Plant Factors Affecting Forage Quality. In: Forage Quality, Evaluation, and Utilization, Eds.: Fahey GC, Collins M, Mertens DR, Moser LE, ASA, CSSA, SSSA, Wisconsin, USA, 115-154.

Özcan H, Ekinci H, Kavdır Y, Yüksel O 2003. Dardanos Yerleşkesi Alan Toprakları. ÇOMÜ Yardımcı Ders Kitabı.

Sağlamtimur T, Gülcan H, Tükel T, Tansı V, Anlarsal E, Hatipoğlu R 1986. Çukurova koşullarında yem bitkileri adaptasyon denemeleri. I. Baklagil yem bitkileri. Çukurova Üni. Ziraat Fak. Dergisi, 1(3): 37-51.

SAS 1999. Institute Inc., SAS OnlineDoc $\AA$, Version 9.0, Cary, NC: SAS Institute Inc.

Tan M, Kurşun Kırcı K, Dumlu Gül Z 2013. Effects of row spacing and seeding rate on hay and seed yield of Eastern Anatolian forage pea (Pisum sativum ssp. arvense L.) ecotype. Turkish Journal of Field Crops, 19(1): 96-100.

Türk M 2005. Farklı ekim sıklıklarının korunganın (Onobrychis sativa L.) kuru ot ve ham protein verimi üzerine etkisi. Ankara Üni. Ziraat Fak. Tarım Bilimleri Dergisi, 11: 292-298.

Türk M, Çelik N 2006. The Effects of different row spaces and seeding rates on the hay and crude protein yields of sainfoin (Onobrychis sativa Lam.). Tarım Bilimleri Dergisi, 12(2): 175-181.

Undersander DJ, Putnam DH, Kaminski AR, Kelling KA, Doll JD, Oplinger ES, Gunsolus JL 1991. Guar. In: Alternative Field Crop Manual. University of Wisconsin Cooperative Extension Service, University of Minnesota Extension Service, Center for Alternative Plant and Animal Products.

Van Soest PJ, Robertson JB, Lewis BA 1991. Methods for dietary fiber, neutral detergent fiber, and nonstarch polysaccharides in relation to animal nutrition. J. Dairy Sci., 74: 3583-3597.

Whistler RL, Hymowitz T 1979. Guar Agronomy, Production, Industrial Use, and Nutrition. Purdue University Press, West Lafayette, IN. 1-118. 